\title{
THE IMPORTANCE OF TIMING OF INTERNATIONALIZATION FOR MULTINATIONAL ENTERPRISES
}

\author{
DOI: 10.17261/Pressacademia.2020.1370 \\ PAP- V.12-2020(34)-p.110
}

\section{Fulya Tasel}

Maltepe University, Faculty of Business and Management Sciences, Istanbul, Turkey fulyatasel@maltepe.edu.tr, ORCID: 0000-0001-6959-5776

\section{To cite this document}

Tasel, F. (2020). The importance of timing of internationalization for multinational enterprises. PressAcademia Procedia (PAP), V.12, p.110.

Permanent link to this document: http://doi.org/10.17261/Pressacademia.2020.1370

Copyright: Published by PressAcademia and limited licensed re-use rights only.

\begin{abstract}
Purpose- The purpose of this study is to emphasize the importance of timing of entrance to international markets for Multinational Enterprises.

Methodology- In this study, the importance of the timing of entrance to international markets is tried to be emphasized with a literature research.

Findings- The literature review reveals that there are many studies about the internationalization processes of businesses (Williams \& Crook 2021; Kabongo \& Okpara, 2019; Meschi, Ricard, \& Moore, 2017). Especially with the effect of today's intense competitive environment and globalization, it is seen that the importance of timing for internationalization for multinational companies is discussed in various dimensions. Conclusion- The objective of this study is to focus on the timing of internationalization of Multinational Enterprises. Timing of entrance to international markets has an important role in terms of the strategies of the firm that are aiming to open up to different markets. Sometimes businesses may have the advantage of entering earlier to the market and getting the advantage of being first mover by putting their internationalization strategies into practice earlier, but they may also face the risks of some unknown factors related to be first mover. On the other side when businesses prefer to enter international markets with a delay, even if it is less costly than entering the market first, it may be possible that this time the timing of entrance will not result in an advantageous market entry strategy (Tuppura et al., 2008). The decision of timing of entrance to international markets is a critical decision for Multinational Enterprises. The possible outcomes of timing of entrance to foreign markets should be evaluated in detail.
\end{abstract}

Keywords: Internationalization, timing of internationalization, multinational enterprises (MNE's)

JEL Codes: D25, F01, F20

\section{REFERENCES}

Kabongo, J., \& Okpara, J. (2019). Timing and speed of internationalization: Evidence from African banks. Journal of Business Research, 102, $12-20$.

Meschi, P.-X., Ricard, A., \& Moore, E. (2017). Fast and Furious or Slow and Cautious? The Joint Impact of Age at Internationalization, Speed, and Risk Diversity on the Survival of Exporting Firms. Journal of International Management, 23, 279-291.

Tuppura, A., Saarenketo, S., Puumalainen, K., Jantunen, A., \& Kyläheiko, K. (2008). Linking knowledge, entry timing and internationalization strategy. International Business Review, 17, 473-487.

Williams, D., \& Crook, T. (2021). Unpacking the age at initial internationalization-performance relationship: A meta-analytic investigation. Journal of Business Venturing Insights, 15. doi:https://doi.org/10.1016/j.jbvi.2020.e00210 